\title{
Influence of polyethylene mulching film of different color and thickness on pine strawberry varieties' yield
}

\author{
Irina Kozlova*, \\ Michurin Federal Sientific Center, Michurin Str., 30, 393774 Michurinsk, Russian Federation
}

\begin{abstract}
Experiments were carried out in 2018-2020 in the FSBSI "FSC named after I. V. Michurin" (Michurinsk, Tambov region) to check the influence of polyethylene mulch of different colors and density on the yield of pine strawberry varieties (Fragaria $x$ ananassa Duch). The experiment was established on the following rows mulching options with polyethylene film produced in Spain: 1. Black, $60 \mu \mathrm{m}$ density (control); 2. Black, $30 \mu \mathrm{m}$ density; 3 . White on black, $30 \mu \mathrm{m}$ density. Allocation is random. Number of plants per plot - 25. Plants of five varieties of pine strawberry were studied - 'Vima Kimberly' (control), 'Alice', 'Malwina', 'Fliar', 'Fleurette', which were planted by "frigo" seedlings with a diameter of up to $15 \mathrm{~mm}$ in rows of $80 \mathrm{~cm}$ width, $15 \mathrm{~cm}$ height, with a distance between two lines of $40 \mathrm{~cm}$ and in a row $-30 \mathrm{~cm}$. The analysis of the experimental results showed that in each fruiting year the higher yield was obtained in the option with black polyethylene film and a density of $60 \mu \mathrm{m}$. Comparative assessment of the studied varieties showed that the reliably high yield was obtained from the 'Fleurette' variety by the years of the experiment: by $18.2 \%, 68.4 \%$ and $51.6 \%$ higher compared to Vima Kimberly variety. In the option with white on black $30 \mu \mathrm{m}$ polyethylene film, 2 - 6 days later onset of the ripening phenophase timing compared to the control was noted, which is due to a lower soil temperature under mulching materials during the development of plants.
\end{abstract}

\section{Introduction}

In modern systems of pine strawberry cultivation, such technological technique as mulching with polyethylene film of different thicknesses and color, non-woven polypropylene material (agrofiber), straw, chips is successfully used [1,2]. As a result of using this agri-technique, there is a decrease in the daily range of temperature variation in the soil layer of 5-15 cm depth and evaporation; this contributes to microclimate creation for successful growth, roots development, optimization of biochemical processes in soil (mineralization), improvement of soil structure, reduction of costs for combating weed plants and preserving pine strawberry fruits in cleanliness $[3,4,5]$.

Previous studies carried out in the Central Chernozem region found the positive influence of black polyethylene film usage for rows mulching on productivity, pine

\footnotetext{
*Corresponding author: koziriv@yandex.ru
} 
strawberry fruit weight in comparison with control with no mulch [6]. Along with this, studies have shown that the use of row mulching with polyethylene film using drip irrigation and fertigation on heavy soils by mechanical composition leads to violation of the root aeration processes. This is one of the reasons causing damage to pine strawberry plants' root system by soil fungi (Phytophthora cactorum, Verticillum dahlia, Rhizoctonia, etc.) [7]. In this regard, research was carried out aimed at optimizing the use of polyethylene film $(60 \mu \mathrm{m})$ and polypropylene non-woven black fabric "Spunbond" $\left(60 \mathrm{~g} / \mathrm{m}^{2}\right)$ in pine strawberry plantations; a technological regulation of their application on soils different in mechanical composition was developed [8].

However, the technical capabilities of plastic mulching materials are improved in line with European standard UNE EN 13491:2006 by using combinations of low density polyethylene (LDPE), linear low-density polyethylene (LLDPE), metallocene resins in order to obtain the greatest efficiency in the microclimate adjustment in the rhizosphere zone of plants, resistance to adverse abiotic environmental factors while reducing the cost of their usage.

In this regard, the study of the impact of polyethylene mulching film of black and white on black colors and $30 \mu \mathrm{m}$ and $60 \mu \mathrm{m}$ densities on the productivity of pine strawberry new introduced varieties is of scientific and practical interest.

\section{Materials and methods}

Experiments were carried out in 2018-2020 in the FSBSI "FSC named after I. V. Michurin" located in Chernozem region (city of Michurinsk). Biological objects were plants of pine strawberry varieties (Fragaria $x$ ananassa Duch) - 'Vima Kimberly' (control), 'Alice', 'Malwina', 'Fliar', 'Fleurette', which were planted in rows with $80 \mathrm{~cm}$ width, $15 \mathrm{~cm}$ height, with distance between two lines $40 \mathrm{~cm}$ and in a row $-30 \mathrm{~cm}$. Distance between the rows $100 \mathrm{~cm}$. In 2017, 'frigo' seedlings were used for planting with a diameter of up to $14 \mathrm{~mm}$, so the peduncles were removed in the first year after planting according to the cultivation technology. The experiment was laid on the following options of row mulching with polyethylene film (Spain) :1.Black, $60 \mu \mathrm{m}$ density (control); 2. Black, $30 \mu \mathrm{m}$ density; 3 . White on black, $30 \mu \mathrm{m}$ density. Allocation is random. Number of plants per plot - 25. Drip irrigation was carried out to maintain $75-85 \%$ of normal moisture in the root layer depending on the phase of plant development. Fertigation was used 1-3 times a week together with drip irrigation using complex water-soluble fertilizers. The soil temperature was measured at a depth of $15 \mathrm{~cm}$ at $2 \mathrm{pm}$ by an electronic soil thermometer. For the comparative study of the yield by experimental options, the biological yield from plants per unit of area was determined [9]. Statistical data processing was carried out according to generally accepted methods, as well as using computer programs Microsoft Excel 2007, Statistics.

\section{Research results and discussion}

In terms of meteorological indicators, the growing season of 2018 differed significantly from the average perennial values for the following weather elements: the range of air temperature variation, up to negative values (2-3 decade of April); relative humidity; deficit of atmospheric precipitation. In the first year of obtaining commercial harvest, experimental results analysis showed that in total yield indicators for introduced pine strawberry varieties amounted to more than $500 \mathrm{~g} / \mathrm{plant}$ except 'Alice' variety - $470.5 \mathrm{~g} / \mathrm{plant}$. No significant effect on productivity increase with application of mulching polyethylene film with $30 \mu \mathrm{m}$ 
density in black and white on black colour was established - 553.8 and $549.4 \mathrm{~g} /$ plants respectively compared to control (density $60 \mu \mathrm{m}$ ) (Table 1).

Table 1. Influence of polyethylene mulching film of different colors and density on strawberry varieties' yield, g/plant (2018)

\begin{tabular}{|c|c|c|c|c|c|}
\hline \multirow[t]{2}{*}{ Variety } & \multicolumn{3}{|c|}{ Polyethylene film option for mulching } & \multirow[t]{2}{*}{ Average } & \multirow{2}{*}{$\begin{array}{l}\text { Yield, } \\
\text { t/ha }\end{array}$} \\
\hline & $\begin{array}{l}\text { black, } 60 \\
\mu \mathrm{m}(\mathrm{c})\end{array}$ & $\begin{array}{l}\text { black, } \\
30 \mu \mathrm{m}\end{array}$ & $\begin{array}{l}\text { white on } \\
\text { black, } 30 \mu \mathrm{m}\end{array}$ & & \\
\hline $\begin{array}{l}\text { 'Vima Kimberly' } \\
\text { (c) }\end{array}$ & 593.5 & 618.0 & 602.6 & 604.7 & 24.2 \\
\hline ' Flair' & 440.5 & 527.2 & 533.2 & 500.3 & 20.0 \\
\hline ' Fluarette' & 703.5 & 744.4 & 695.2 & 714.4 & 28.6 \\
\hline ' Alice' & 638.5 & 373.6 & 399.4 & 470.5 & 18.8 \\
\hline ' Malwina' & 772.5 & 505.9 & 516.5 & 598.3 & 23.9 \\
\hline Average & 629.7 & 553.8 & 549.4 & & \\
\hline $\mathrm{LCD}_{05}$ by varieties & & & & 50.07 & \\
\hline $\mathrm{LCD}_{05}$ by film & & & & 38.79 & \\
\hline
\end{tabular}

Comparative assessment of the studied varieties showed that a reliably high yield was obtained in the variety 'Fleurette' - by $18.2 \%$ compared to control. This variety had a higher yield in options: black film, $60 \mu \mathrm{m}(18.5 \%)$ and black film, $30 \mu \mathrm{m}(20.5 \%)$ compared to control.

The growing season of 2019 was characterized by deviations in hydrothermal regime from the average perennial values, especially during berries' formation and ripening period, which was manifested in increased air temperatures, lack of precipitation, low relative air humidity compared to perennial values.

In the second year of obtaining commercial harvest of pine strawberry varieties, analysis of experimental material showed that in total for five varieties there was no significant effect on the yield increase at application of mulching polyethylene film with 30 $\mu \mathrm{m}$ density in white on black and black colors $(822.4 \mathrm{~g} / \mathrm{plant}$ and $781.0 \mathrm{~g} / \mathrm{plant}$ respectively) compared to the control density of $60 \mu \mathrm{m}(752.2 \mathrm{~g} / \mathrm{plant})\left(\mathrm{F}_{\mathrm{f}}<\mathrm{F}_{\mathrm{st}}\right)$ (Table 2$)$.

Table 2. Influence of polyethylene mulching film of different color and density on the strawberry varieties' yield, g/plant (2019)

\begin{tabular}{|l|c|l|l|l|l|}
\hline \multirow{2}{*}{ Variety } & \multicolumn{3}{|l|}{ Polyethylene film option for mulching } & Average & $\begin{array}{l}\text { Yield, } \\
\text { t/ha }\end{array}$ \\
\cline { 2 - 6 } & $\begin{array}{l}\text { black, } \mathbf{6 0} \\
\boldsymbol{\mu m} \mathbf{( c )}\end{array}$ & $\begin{array}{l}\text { black, } \\
\mathbf{3 0} \mathbf{~} \mathbf{m}\end{array}$ & $\begin{array}{l}\text { white on black, } \\
\mathbf{3 0} \mathbf{~ \mathbf { m }}\end{array}$ & & \\
\hline 'Vima Kimberly' (c) & 566.7 & 622.6 & 760.2 & 649.8 & 26.0 \\
\hline ' Flair' & 569.2 & 540.6 & 573.4 & 561.1 & 22.4 \\
\hline ' Fluarette' & 885.4 & 1212.7 & 1186.3 & 1094.8 & 43.8 \\
\hline ' Alice' & 714.6 & 66.8 & 671.8 & 684.4 & 27.4 \\
\hline ' Malwina' & 1025.0 & 862.3 & 920.4 & 935.9 & 37.4 \\
\hline Average & 752.18 & 781.0 & 822.4 & & \\
\hline LCD $_{05}$ by varieties & & & & 98.7 & \\
\hline LCD $_{05}$ by film & & & & Ff $<$ Fst & \\
\hline
\end{tabular}

An assessment of plastic mulching materials influence on the productivity of five introduced pine strawberry varieties showed that on average for varieties, this indicator ranged from $561.1 \mathrm{~g} /$ plant ('Fliar' v.) to $1094.8 \mathrm{~g} /$ plant ('Fleurette' v.). Reliably high productivity was established in all options of 'Fleurette' variety - by $68.5 \%$ and 'Malwina' by $44.0 \%$ compared to control.

At the beginning of the 2020 growing season, there was a lack of productive moisture in the soil due to early snow meltdown and the deficit of atmospheric precipitation by $8.5 \mathrm{~mm}$, as well as spring frosts after snow melt down from $-0,7^{0} \mathrm{C}$ to $-7.6^{0} \mathrm{C}$. The summer period was characterized as moderately warm. The varying range of air temperature indicators contributed to an increase in the duration of phenological phases and later terms of their 
onset, especially in the first half of vegetation. As with previous years of research, there was an unsustainable and insufficient precipitation.

In established weather conditions, the results' analysis of the third experimental year showed that in total for five varieties there was no effect on the increase in yield by the application of mulching polyethylene film with $30 \mu \mathrm{m}$ density of white on black and black colors $(651.6 \mathrm{~g} / \mathrm{plant}$ and $549.7 \mathrm{~g} /$ plant respectively) compared to control with $60 \mu \mathrm{m}$ density (753.8 g/plant) (Table 3$)$.

Table 3. Influence of polyethylene mulching film of different color and density on the strawberry varieties' yield, g/plant (2020)

\begin{tabular}{|l|l|l|l|l|l|}
\hline \multirow{2}{*}{ Variety } & \multicolumn{3}{|l|}{ Polyethylene film option for mulching } & Average & $\begin{array}{l}\text { Yield, } \\
\text { t/ha }\end{array}$ \\
\cline { 2 - 5 } & $\begin{array}{l}\text { black, 60 } \\
\boldsymbol{\mu m} \mathbf{( c )}\end{array}$ & $\begin{array}{l}\text { black, } \\
\mathbf{3 0} \boldsymbol{\mu \mathbf { m }}\end{array}$ & $\begin{array}{l}\text { white on } \\
\text { black, 30 } \boldsymbol{\mu m}\end{array}$ & & \\
\hline 'Vima Kimberly' (c) & 766.9 & 498.4 & 573.7 & 613.0 & 24.5 \\
\hline ' Flair' & 727.2 & 580.9 & 717.2 & 675.1 & 27.0 \\
\hline ' Fluarette' & 918.2 & 868.5 & 1001.4 & 929.4 & 37.2 \\
\hline ' Alice' & 824.0 & 329.9 & 469.3 & 541.1 & 21.6 \\
\hline ' Malwina' & 532.4 & 470.8 & 495.4 & 499.5 & 20.0 \\
\hline Average & 753.8 & 549.7 & 651.4 & & \\
\hline LCD $_{05}$ by varieties & & & & 50.95 & \\
\hline LCD $_{05}$ by film & & & & 65.80 & \\
\hline
\end{tabular}

As in previous years, a reliably high yield was established in 'Fluarette' variety - 929,4 $\mathrm{g} /$ plant, as well as 'Flair' variety $-675.1 \mathrm{~g} /$ plant, which exceeds control by $51.6 \%$ and $10.1 \%$ respectively.

As a result of statistical data processing, it was established that during the experiment the influence force characteristic $\left(\eta^{2}\right)$ of the variety genotype amounted to $47.69 \%-58.3 \%$ and of mulching film $-9.2 \%-17.68 \%$.

In research carried out in Iran, the influence of mulching film color on the pine berry harvesting timing [10] was indicated. Based on the analysis of our observations on the plants' development, the influence of white on black $30 \mu \mathrm{m}$ polyethylene film on the onset of full blossoming phenophases and the beginning of ripening was established by: $5-6$ days in the first year of the experiment and 2 - 5 days later compared to control in the second and third year, which is associated with lower soil temperature under mulching materials (Figure 1).

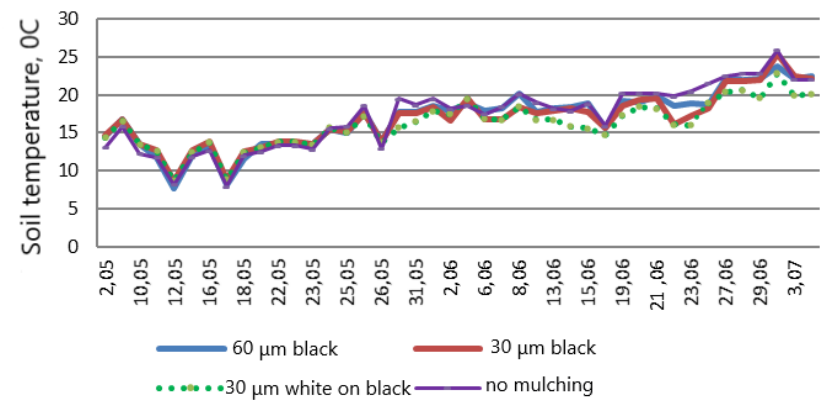

Fig. 1. Soil temperature under various polyethylene film at a depth of $15 \mathrm{~cm}$ at $2 \mathrm{pm}$

Based on the measurements, soil temperature at $15 \mathrm{~cm}$ depth under black polyethylene mulching film was higher compared to white on black by $0.1 \ldots 2.5^{\circ} \mathrm{C}$, which is consistent with literary data $[11,12]$. For the period of measurements, the sum of positive soil temperatures in this option with white on black film was lower by $34.9^{\circ} \mathrm{C}$ compared to control, by $28.1^{\circ} \mathrm{C}$ compared to black film of $30 \mu \mathrm{m}$ density and $45.6{ }^{\circ} \mathrm{C}$ - without 
mulching materials. Thus, pine strawberry cultivation on the rows with white on black film will allow to influence the ripening timing in open ground.

\section{Conclusions}

Based on the analysis of the obtained data,no statistically significant effect of the studied 30 $\mu \mathrm{m}$ density and black and white on black color polyethylene mulch on the yield was established in comparison to the control - $60 \mu \mathrm{m}$ density, black color.

Comparative assessment of the studied varieties showed that a reliably high yield was obtained in the 'Fleurette' variety according to the years of the experiment - higher by $18.2 \%, 68.4 \%$ and $51.6 \%$ compared to Vima Kimberly variety.

During the experimental period, influence of white on white on black $30 \mu \mathrm{m}$ polyethylene film on 2 - 6 days later onset of the full blossoming phenophase timing compared to the control was noted, which is due to a lower soil temperature under mulching materials during the development of plants.

\section{References}

1. AliRAM, E.A. Radwan, J. of Agricultural, Enviromental Science, 7, 167 (2008)

2. Julie M. Tarara, HortScience, 35(2), April, 169 (2000)

3. L. Fan, V. Roux, C. Dubé, D. Charlebois, S. Tao, S. Khanizadeh, Agricultural and Food Science, 21, 132 (2012)

4. M.J. Kasperbauer, Published in Crop Science, 40, 171 (2000)

5. S. Shiukhy, M. Raeini-Sarjaz, V. Chalavi, International Journal of Biometeorology, 59, 1061 (2015)

6. I.I. Kozlova, Fruit growing and berry growing in Russia, 32(1), 223 (2012)

7. I.I. Kozlova, N.Ya. Kashirskaya, I.N. Chesnokova, Fruit growing and berry growing in Russia, XXXVI(1), 282 (2013)

8. I.I. Kozlova, O.N. Budagovskaya. I.N. Kulakov, Application of sheltering and mulching materials in stock and commercial pine strawberry plantations, 44 (2016)

9. E.N. Sedova, T.N. Ogoltsova, Program and methodology of variety study of fruit, berry and nut crops, 417 (1999)

10. S. Shiukhy, M. raeini Sarjaz, V. Chalavi. J. of Novel Applied sciences, 3-S2, 1573 (2014)

11. I. Ochmian, J. Grajkowski, P. Kirrchhof, Rocz. Ar Pozn, CCCLXXXIII(41), 357 (2007)

12. A.A. Shokouhian, A. Asghari, AEBE, 1 (2015) 